\title{
Staff Development and Promotion as Correlates of Teachers' Job Satisfaction in Secondary Schools in Ekiti State, Nigeria
}

\author{
B. B. Arogundade \\ Department of Educational Management, Faculty of Education, Ekiti State University, Ado- Ekiti, Nigeria
}

Received: 9 October 2019; Revised: 5 November 2019; Accepted: 18 November 2019; Published: 3 December 2019

Abstract: The study examined the relationship between staff development, promotion and teachers' job satisfaction in secondary schools in Ekiti State. The study adopted a descriptive research design of the survey type. The population of this study consisted of all the 7,538 teachers in the 203 public secondary schools in Ekiti State. The sample for the study consisted of 800 respondents (640 class teachers, 128 Head of Departments and 32 Vice Principals) from 32 public secondary schools in Ekiti State via multistage sampling procedure which involved simple random, stratified and purposive sampling techniques Two sets of instruments tagged "Staff Development and Promotion Questionnaire (SDPQ)" and "Teachers Job Satisfaction Questionnaire (TJSQ)" were used to collect relevant data for the study. The face and content validity of the instruments were determined by Educational Management experts, experts in Test and Measurements. The test retest method of reliability was used to ascertain the reliability of the instruments. The reliability coefficient of 0.91 obtained for SDPQ while 0.84 was obtained for TJSQ. The research hypotheses were tested using Pearson's Products Moment Correlation at 0.05 level of significance. Findings revealed the significant relationship between staff development, promotion and teachers job satisfaction. It was recommended that regular staff development programmes should be organized by government for continuous professional development of teachers. It was also recommended that teachers should be promoted as and when due and whenever there is delay in promotion, the arrears of the financial benefit of such promotion should be paid in full.

Keywords: Staff development, Promotion, Teacher job satisfaction, Secondary school.

\section{Introduction}

The role of education in the society is multidimensional. It a means of empowering children and adult to become active participants in the transformation of their societies through learning of values, attitudes and behaviours that would enable individuals to learn how to live together in a world characterized by diversity and pluralism. Education is not only a social services, it is an instrument of political and economic socialization that enable the learner to know right from wrong and particularly to know various privileges and basic human rights. Education also makes the individual worth living and worth living with (Owojori and Asaolu, 2010). The national policy on education categoricalized level of education into primary, secondary and tertiary education in Nigeria.

All over the world, both in the developing and the developed countries, secondary school exists to cater for children of approximately the same age group and are exposed to approximately the same curricular of reading, writing and arithmetic. The duration of secondary education varies from country to country. However, in Nigeria, the duration is six years according to the 6-3-3-4 education system.

It has been observed that without teachers the educational objectives as it specified in the national policy on education cannot be realized. Indeed, planners of education may establish new schools, effect changes on the structures and curriculum, recommend and prescribed teaching methods and teaching aids but at the end the teacher will be responsible for implementation of educational policies. The teachers appear to be a model and they are consciously imitated. According to Waga (2010), the teacher is the pivot of any educational system. In fact, teachers are the strength of the nation. It could be observed that teacher's positive attitude towards teaching and higher aspiration determines their level of satisfaction.

Satisfaction is the contentment and a pleasurable or positive emotional state, resulting from the appraisal of one's job experiences. The optimistic feeling about work and environment around job lead someone towards satisfaction (Uwe, 2006). It is the extent to which employees wants or like to perform work. 
The relevance of teachers' job satisfaction is very crucial to the long - term growth of any educational system around the world. Job satisfaction in this context is the ability of the teaching job to meet teachers' need and improve their job satisfaction. Considering the teacher job satisfaction, it has been observed that the existing salary structure, benefits, working conditions and recognition do not satisfy their basic needs compare to other sectors of the economy that have better working conditions.

In the recent time, teachers complained bitterly about their job satisfaction, in turning to their job dissatisfaction. And as such, teachers appear to develop a kind of lukewarm attitude, inactive, lack of commitment, disloyal attitude, less concerned for students, while some abandoned teaching job to look for better job where they are likely to derive job satisfaction. However, the observed deterioration in the teachers' job satisfaction in secondary schools is a reflection of lack of staff development and promotion in the schools.

Considering the importance of staff development and promotion and the practical implications on teachers' job satisfaction in secondary schools, this study investigated the relationship between staff development and promotion of teachers and secondary school teachers' job satisfaction in Ekiti State.

Staff development could be thought of as processes designed to enhance the professional knowledge, skills, and attitudes of teachers so that they might, in turn, improve the learning of students. According to Nakpodia (2008), staff development programme is a process for continuous up-dating of teachers' knowledge, skills and interests in chosen field. It is a means for continuous professional growth, which encourages the extension of technical assistance by teachers educators. In-service teacher education is an integral part of staff development programme, which is organized for teachers while in service. Aitken (2004) defines in-service training as the on-going training of practicing teachers, which is typically arranged by school boards or teaching service commission that employ the teachers.

It appears that government agencies in charge of staff development are not performing up to the expectation in the area of updating teachers' knowledge. The researcher observed that some teachers have spent more than 5 years in the service and yet has not got the opportunity to attend any seminar, conference or workshop. This seems to be discouraging and do not allow most of the teachers put in their best. Even those who are ready to put in their best might not be equipped with the latest pedagogical skills of teaching. This appears to contribute greatly to job dissatisfaction among teachers in secondary schools.

Promotion refers to the upward mobility of an employee which accompanied by greater responsibility and higher status, greater skills and increased salary. Though the duties assigned to promoted staff in education might not change, the title and possibly the level at which the duties are performed change. Promotion is a positive reward that increases the morale of employees and motivates them to work harder towards the attainment of the education objectives.

It seems the backlog of delayed promotions of teachers have hindered the level of job satisfaction across all the secondary schools in Ekiti State. The researcher observed that the last batch of promotion done for teachers was in the year 2012. It means that teachers who were due for promotion since 2013 are yet to be promoted. It is the desire of every teacher to reach the peak of their chosen career but when this is not certain, it may likely affect their level of job satisfaction. It is of no doubt that teachers who are promoted as and when due will be satisfied with their job and hence put in their best to the job.

\subsection{Statement of the Problem}

In the Nigerian education sector, teachers have complained about the inadequacies in the areas of staff development and promotion. These deficiencies seem to lead to teachers' dissatisfaction on their teaching job. Observation shows that some teachers abandoned the teaching job to look for better job where they will likely have job satisfaction.

The researcher observed that this non-commitment to teaching profession seems to arise as a result of inadequate staff development programme and delayed promotion. Some teachers appear not having interest in their job as a result of kind of treatment they are given. Hence, this study examined the relationship between staff development, promotion and teachers' job satisfaction in Ekiti State, Nigeria.

\subsection{Purpose of the Study}

The study examined the relationship between staff development, promotion and teachers' job satisfaction in secondary schools in Ekiti State.

\subsection{Research Questions}

The following research questions are raised for the study:

Contemporary Research in Education and English Language Teaching
ISSN: $2641-0230$
Vol. 1, No. $3, p p .41-44,2019$
DOI: $10.33094 / 26410230.2019 .13 .41 .44$
C) 2019 by the authors; licensee Learning Gate


1. Is there any relationship between staff development and teachers' job satisfaction in secondary schools in Ekiti State?

2. Is there any relationship between promotion and teachers' job satisfaction?

\section{Method}

The descriptive research design of the survey type was adopted in this study. The population of this study consisted of all the teachers in the public secondary schools in Ekiti State. As at the time of this study, there were 203 public secondary schools with 7,538 teachers (Source: Ekiti State Teaching Service Commission, 2017). The sample for the study consisted of 800 respondents was made up of 640 class teachers, 128 Head of Departments and 32 Vice selected from 32 schools using multistage sampling procedure. Two self-designed research instrument tagged "Staff Development Promotion Questionnaire" (SDPQ) and "Teachers Job Satisfaction Questionnaire" (TJSQ) were used to collect relevant data for the study. The instruments were validated by experts. The reliability co-efficient of 0.90 was obtain for Personnel Management Questionnaire (PMQ), while a reliability co-efficient of 0.84 was obtain for Teacher's Job Satisfaction (TJSQ). All hypotheses were tested at 0.05 level of significance.

\section{Results}

The data obtain through the research instrument were analysed and the hypotheses were tested at 0.05 level of significance.

Hypothesis 1: There is no significant relationship between staff development and teachers' job satisfaction.

Table 1.

Correlation between staff development and teachers' job satisfaction

\begin{tabular}{|l|l|l|l|l|l|}
\hline Variables & No of Schools & Mean & Stand Dev & r-cal & r-tab \\
\cline { 1 - 4 } Staff Development & 32 & 10.36 & 0.91 & \multirow{2}{*}{$0.459^{*}$} & \multirow{2}{*}{0.349} \\
\hline Job Satisfaction & 32 & 53.97 & 2.56 & & \\
\hline
\end{tabular}

Note: $* \mathrm{P}<0.05$

Table 4 showed $r$-cal (0.459) is greater than r-table (0.349) at 0.05 level of significance. The null hypothesis is rejected. This implies that there is significant relationship between staff development and teachers' job satisfaction.

Hypothesis 2: There is no significant relationship between promotion and teachers' job satisfaction.

Table 2.

Correlation between promotion of teachers and teachers' job satisfaction

\begin{tabular}{|l|l|l|l|l|l|}
\hline Variables & No of Schools & Mean & Stand Dev & r-cal & r-tab \\
\hline Promotion of Teachers & 32 & 9.23 & 0.83 & \multirow{2}{*}{$0.433^{*}$} & \multirow{2}{*}{0.349} \\
\cline { 1 - 3 } Job Satisfaction & 32 & 53.97 & 2.56 & & \\
\hline
\end{tabular}

Note: $* \mathrm{P}<0.05$

Table 2 showed $r$-cal (0.433) is greater than r-table (0.349) at 0.05 level of significance. The null hypothesis is rejected. This implies that there is significant relationship between promotion of teachers and teachers' job satisfaction.

\section{Discussion of the Findings}

The study revealed the relationship between staff development, promotion and teachers'job satisfaction in secondary schools in Ekiti State. It was discovered from the finding that there is a significant relationship between staff development and teachers' job satisfaction. The reason for this finding might be due to the fact that when teachers are professionally developed, they are likely to be satisfied with their job. Akinbode (2006) in an earlier study had established that investment in the form of development training was a crucial factor in the development of job commitment. The result of the study showed that teachers who had low commitment to the profession prior to training became highly committed after they were given opportunity to go for inservice training. Thus, in-service training served to boost teachers' moral and thus, engendered positive work performance and satisfaction among them. This finding is in consonance with Aaronson (2007) and Betts 
(2003) who all found a significant relationship between staff development and teachers' job satisfaction. The implication of this finding is that development of teachers is crucial in ensuring high job satisfaction.

It was also revealed that there is significant relationship between promotion of teachers and teachers' job satisfaction. When promotion of teachers are given top priority, teachers are likely to be motivated which can bring about job satisfaction. This finding supports the contention of Akinbode (2006) and Arabi (2000) who concluded that a significant relationship existed between regular promotion and job satisfaction. However this findings contradicted the submission of Gould-Williams (2007) who found no relationship between promotion and job satisfaction. The implication of this finding is that prompt and timely promotion of teachers will lead to job satisfaction.

\section{Conclusion}

Base on the findings of the study, it was concluded that Staff development, promotion and teachers' job satisfaction were related. Moreover, staff development and promotion has impact on teachers' job satisfaction.

\section{Recommendation}

Based on the findings, it was recommended that;

1. Regular staff development programmes should be organized by government for continuous professional development of teachers.

2. That teachers should be promoted as and when due and whenever there is delay in promotion, the arrears of the financial benefit of such promotion should be paid in full.

\section{References}

Aaronson, D. ( 2007). Teachers and student achievement in the Chicago public high schools. Journal of Labour Economics, 25, 95-135.

Aitken, J.E. (2004). In-service training for teachers in New Zealand schools, what's New Publications. North American Association of Educational Negotiators (NEAN) 15(1), 3-5.

Akinbode, J.F. (2006). Staff development.Journal of the Institute of Personnel Management of Nigeria 12(2), 52-57.

Betts, J. R. (2003). Determinants of student achievement: New Evidence from San Diego. San Diego: Public Policy Institute of California

Ekiti State Teaching Service Commission. (2017).

Gould-Williams, J. (2007). HR practices, organizational climate and employee outcomes: evaluating social exchange relationships in local government. International Journal of Human ResourceManagement, 18 (9), 1627 - 1647

Nakpodia, E.D. (2008). The role of Educational administration in the promotion of in-service teacher education for primary school teachers in Nigeria.Current issues in educational management in Nigeria, Benin City: Ambik Press.

Owojori and Asaolu, (2010).Critical Evaluation of Personnel Management Problems in Nigerian School System.International Journal of Educational Science. 2(1):1-11

Uwe, F.U. (2006). Reward systems and teachers' attitude to work in Northern educational zone of Cross River State, Unpublished M.Ed Thesis, Department of Educational Administration and Planning, University of Calabar.

Waga, R.A. (2010). Job Satisfaction and Dissatisfaction among teachers in public secondary schools in Kisumu East and West Districts, Kenya. Unpublished Master of Education thesis ,Maseno University, Kenya. 